УДК 631.1.027:631.11

(C) 2012

Фастівець Н. П., викладач

Полтавська державна аграрна академія

\title{
ДОСВІД РЕАЛІЗАЦІЇ МАРКЕТИНГОВОЇ СТРАТЕГІЇ В ДІЯЛЬНОСТІ ПІДПРИЕМСТВ АПК
}

\section{Рецензент - доктор економічних наук, професор Х. 3. Махмудов}

\begin{abstract}
Розглядаються теоретичні аспекти розвитку маркетингових стратегій, їх удосконалення на основі раціональних підходів, можливих комбінацій застосування та досвід їх реалізаџії в діяльності сучасних агропромислових підприємств Украӥни. Формування маркетингової стратегї - це найсуттєвіший і найскладніший етап досліджень. Розробка стратегічних маркетингових принципів повинна трунтуватися на системному підходi, щзо відповідає дотриманню об' єктивних економічних законів, передусім попиту і пропозииії та тендениій розвитку об'єкта планування. Маркетингові стратегії конкретизуються иляхом визначення принципів поведінки всіх учасників ринку та встановлення генеральної лінії діяльності підприсмства.
\end{abstract}

Ключові слова: ринкове середовище, агропромислові підприємства, маркетингові стратегії, доведеність і обтрунтованість, діяльність, інвестииї̈ та інновачії, конкурентоспроможність.

Постановка проблеми. Ринкове середовище, в якому функціонують агропромислові підприємства в Україні, є несприятливим, із високим ступенем невизначеності, тому підприємства, 3 одного боку, повинні пристосовуватися, з іншого, - впливати на середовище, поступово трансформуючись, із урахуванням потреб і можливостей товаровиробників. Діяльність у сфері АПК завжди мала свої особливості. Без раціональних маркетингових підходів неможлива задовільна робота жодного агропромислового підприємства [11, c. 25].

Одна 3 найбільших проблем, що виникає у практиці ведення бізнесу, стосується обгрунтованості рішень, що приймаються. У маркетинговій практиці, особливо в 90-ті роки минулого століття, коли не було достатньої кількості кваліфікованих фахівців-маркетологів, у нашій країні нерідко на маркетингові посади зараховувалися фахівці без відповідної економічної освіти. Рішення приймалися інтуїтивно, під час без належного обгрунтування. У сучасних умовах ухвалення ірраціональних рішень уже неможливе, - ціна помилки обчислюється сумою з багатьма нулями. Це викликало попит на фахівців, які володіють науково-практичним апаратом, що дає змогу приймати може не геніальні, проте гарантовано правильні управлінські рішення. Доведеність і обгрунтованість - основа основ наукового підходу до ухвалення рішень, які гарантують стабільну «якість» рішень, що приймаються. Це забезпечує сталий розвиток компанії в довгостроковій перспективі [2, с. 72-73].

Аналіз останніх досліджень і публікацій, у яких започатковано розв'язання проблем маркетингових стратегій та їх комбінацій вперше знаходимо в теоретичних дослідженнях зарубіжних науковців-економістів, зокрема, у працях М. Е. Портера [8], Ж.-Ж. Ламбена [4] та вітчизняних авторів, які досліджують можливості реалізації маркетингових підходів у діяльності підприємств АПК, - І. В. Артімонова [1], Д. Л. Мельник [5], У. Р. Сухорська [10], О. А. Юрченко [11].

Мета і завдання досліджень. Метою дослідження $\epsilon$ виокремлення маркетингових стратегій у діяльності підприємств агропромислового комплексу та аналізу практичного досвіду їх використання в провідних агропромислових об'єднаннях України.

Завдання: визначити переваги застосування маркетингових стратегічних підходів у діяльності конкретних агропромислових фірм, а саме ВАТ «Миронівський хлібопродукт» і ТОВ «Комплекс Агромарс».

Матеріали і методи досліджень. Матеріали дослідження відображають основні статистичні дані офіційних сайтів агропромислових об'єднань ВАТ «Миронівський хлібопродукт» i TOB «Комплекс Агромарс» й наукові пошуки сучасних економістів-маркетологів. Використовуються методи емпірико-теоретичного рівня пізнання (збір наукових фактів, порівняння, аналогія, опис) та узагальнюючого рівня (індукція та дедукція, аналіз і синтез, можливості формалізації та моделювання наукових досліджень).

Результати досліджень. У результаті проведеного аналізу стратегічної маркетингової діяльності в аграрному секторі України виявлено на- 
ступні проблеми та недоліки:

- стратегічна маркетингова діяльність на рівні сільськогосподарських підприємств має безсистемний, безпрограмний характер;

- маркетинг переважно здійснюється сільськогосподарськими підприємствами самостійно в умовах відсутності достатньої поінформованості й проведення аналітичної роботи;

- рівень забезпечення маркетингу кадровим, науково-методичним, фінансовим та іншим потенціалом у більшості аграрних підприємств недостатній для використання наявних ринкових можливостей [11, с. 27].

Ефективна робота національних підприємств як на внутрішньому, так і на зовнішньому ринках потребує знань і врахування об'єктивних ринкових законів, вміння організовувати регулярне отримання та оперативне використання ринкової інформації, вміння підвищити конкурентоспроможність своєї продукції та інше. Все це є елементами маркетингу - однієї з найбільш ефективних концепцій ринкової економіки. Саме на основі результатів маркетингової діяльності проводиться більшість комерційних операцій на світовому ринку. Про значення маркетингу в глобальних масштабах свідчать результати спеціальних досліджень, відповідно до яких понад $75 \%$ комерційних невдач на світовому ринку відбувається 3 причин, пов'язаних із помилками у маркетинговій діяльності, менше 25 \% зумовлено іншими причинами [10, с. 220].

У країнах із високим рівнем розвитку економіки маркетинг уже перетворився в одну з передових галузей сучасного господарства. За визначенням американських дослідників, питома вага маркетингової стратегї в загальній стратегії фірми становить близько $80 \%$ [11, с. 28].

Проте в Україні тривалий час панували, а в багатьох випадках і досі побутують думки про те, що в сільському господарстві маркетинг не потрібний або ж необхідні лише його певні атрибути [3, с. 131]. Відповідно до досліджень, що були проведені в Україні, досить незначна кількість компаній, на жаль, надає належної уваги стратегічному плануванню. Так, наприклад, частка підприємств, які визнають пріоритет стратегічного планування - 21,4\% (м. Київ), а у Донецьку тільки 14,6 \% [11, с. 28].

Вивчаючи історію економічного розвитку України, можна зробити висновок, що головною причиною гальмування розвитку підприємств АПК України на принципах маркетингу є важкі наслідки господарювання в умовах централізованої адміністративної економіки колишнього
СРСР. Офіційна радянська ідеологія заперечувала більшість аспектів маркетингової діяльності, проте не можна повною мірою стверджувати, що маркетингу в СРСР взагалі не було [3, с. 132].

Однією з головних проблем, яка перешкоджає активному впровадженню маркетингу в українську економіку, є неоднозначність трактування основних його понять, зокрема стратегічного визначення, розрив між теорією і практикою застосування цих понять [10, с. 221]. Обгрунтування доцільності застосування маркетингових стратегій, підтверджена досвідом провідних зарубіжних компаній, ще не набула широкої популярності в Україні [5, с. 205].

В Україні маркетингові стратегії та їх відповідні методи використовуються відносно недавно й лише на окремих підприємствах. Як свідчить проведене дослідження практиків стратегічного маркетингового планування на вітчизняних підприємствах, більшість опитаних керівників (54 \%) відзначають, що науковий підхід до визначення та використання маркетингових стратегій є одним із найважливіших чинників ефективної діяльності підприємства. Однак лише 3 \% опитаних підтвердили постійне здійснення стратегічного маркетингового планування на їхніх підприємствах, 40 \% - його періодичне використання, $25 \%$ засвідчили, що воно використовується рідко, решта (12\%) практично не використовують стратегічне маркетингове планування $[10$, c. 221$]$.

Перший етап відноситься до еволюції маркетингу в АПК України періоду середини та кінця 90-х років XX століття. Проте мова йде, насамперед, про I та III сфери АПК (харчова промисловість і переробка сільськогосподарської сировини, сервісне обслуговування, а також виробництво окремих ресурсів для сільського господарства). Безпосередньо в аграрному секторі відповідні процеси розпочалися у 2000 році, після масового реформування колишніх КСП та виникнення нових агропромислових формувань (агрохолдингів). Інвесторами останніх часто були або власники переробних підприємств, або ті, хто займався постачанням матеріально-технічних ресурсів для села. Головним для нових власників було відновити (по суті заново) аграрне виробництво, яке знаходилося практично у занедбаному стані, та зайняти вільні ніші на ринку сільськогосподарської сировини [3, с. 135-136].

Світовий досвід переконує: маркетинг є засобом перспективного розвитку підприємств. Стратегічне маркетингове планування застосовується практично всіма ефективно функціонуючими компаніями у країнах із розвинутою рин- 
ковою економікою [10, с. 221]. Відомо, що забезпечення ефективності функціонування вітчизняних господарюючих суб'єктів агробізнесу в сучасних умовах безпосередньо залежить від використання ними маркетингового інструментарію.

Слід зазначити, що нині чимало вітчизняних виробників, наслідуючи сучасні концепції маркетингу, вводять до організаційної структури своїх підприємств служби маркетингу, які активно застосовують інноваційні маркетингові технології. Водночас маркетингом, як визначеною концепцією діяльності, керуються лише окремі підприємства, зокрема в Україні; це передусім транснаціональні корпорації [1, с. 84].

У такий спосіб провідні ролі в агропромисловому секторі України зайняли такі світові компанії як «Vimm-Bill-Dann», «Unimilk», «Danone», «Lactalis» (ринок молокопродуктів), «Glenkor International AG», «Alfred C. Toepfer International Group», «Cargill», «WJ» (торгівля зерном), «Baltic Beverage Holding», «InBev» (ринок пива), «Kraft Foods» (кондитерський ринок) та «Nestle» (кондитерський ринок і плодоовочева консервація), «Bunge» та «Cargill» (ринок соняшникової оліі), «Рерsі» (ринок соків - придбала ТОВ «Сандора»), «Coca-Cola», а також чимало інших.

Ті українські компанії, які відчувають, що не зможуть сконцентрувати необхідний рівень інвестиції для протистояння транснаціональним компаніям, продають свій бізнес або готують для продажу, очікуючи сприятливої ситуації. Інші компанії розуміють, що діяти треба тими ж методами, як і світові лідери, скуповуючи виробничі активи як в Україні, так і за ії межами, завойовуючи ринки інших країн. Так діють передусім лідери вітчизняного горілчаного (компанії «Nemiroff Холдинг», «Хортиця», «Союз-Віктан», «Оверлайн», «Олімп») і кондитерського ринків («Roshen», «АВК», «Конті»).

Можливий також варіант співпраці зі світовими лідерами шляхом створення спільного підприємства, продажу частини бізнесу або виходу на світовий фондовий ринок, наприклад, через IPO.

Так зробив у 2006 році один із лідерів із виробництва цукру в Україні - компанія Astarta Holding N.V., - продавши $20 \%$ акцій через Bapшавську фондову біржу, а в 2008 році лідер вітчизняного м'яса птиці, у тім числі ВАТ «Миронівський хлібопродукт», розмістив $20 \%$ своїх акцій на основному майданчику Лондонської фондової біржі [3, с. 137] (див табл.).
ВАТ «Миронівський хлібопродукт» - одна 3 провідних агропромислових компаній України. Основною діяльністю групи, заснованої в 1998 році, $є$ розведення птиці, виробництво та продаж продуктів із м'яса курки - переважно під маркою «Наша ряба», яка за останні 8 років досягла рівня $95 \%$ - пізнаваності бренда серед споживачів і суттєво обігнала найближчих конкурентів [6].

У рейтингу «50 найпопулярніших брендів», підготовленому журналом «Фокус» у середині вересня 2010 року, перше місце виборов провідний бренд «Миронівського хлібопродукту» «Наша Ряба». На кінець першого півріччя 2010 року визнання бренду становило $97 \%$. Нині в Україні розташовано близько 2500 фірмових торгових точок, і ця цифра щомісяця збільшується.

Бренд найкращої курятини обійшов переможця минулого року (найвідоміший бренд кондитерської продукції), перевищивши його досягнення за обсягом продажів на 1 міліард гривень. За 2009 рік ВАТ «Миронівський хлібопродукт» продав охолодженої курятини на 3,326 млрд грн, що більше ніж на 1 мільярд перевищує цей показник за 2008 рік [9, с. 4].

ВАТ «Миронівський хлібопродукт» $є$ вертикально інтегрованою компанією. Керуючись принципом: «Якщо прагнеш зробити щось добpe, зроби це сам», ВАТ «Миронівський хлібопродукт» контролює повний виробничий цикл отримання товарного м'яса курки. Компанія самостійно вирощує зерно для постачання заводів із виробництва комбікормів; виготовляє корми для своїх птахофабрик із вирощування батьківського поголів'я і фабрик із виробництва м'яса птиці. Завдяки власному парку вантажівокрефрижераторів у кількості понад 430 машин займається доставкою власної продукції в дистрибуційні центри та франчайзингові точки по всій території України. Переважна частина виробів реалізовується через мережу фірмових франчайзингових точок продажу [6].

За даними Української аграрної конфедерації, у січні-лютому 2010 р. обсяги виробництва м'яса птиці в Україні зросли на $13 \%$, у порівнянні з аналогічним періодом 2009 р., і на $23 \%$ порівняно з відповідним періодом 2008 року.

Можливості компанії дають змогу щотижня вирощувати понад 3,5 мільйонів бройлерів для подальшого виробництва близько 27,5 тис. тонн м'яса птиці на місяць [9, с. 4]. 
Напрями діяльності об’єднання ВАТ «Миронівський хлібопродукт», 2010 р.

\begin{tabular}{|c|c|}
\hline Напрям діяльності & Активи \\
\hline Зернозаготівля & $\begin{array}{c}\text { ТОВ «Зернопродукт»: вирощування зернових культур. ЗАТ «Орель- } \\
\text { Лідер»: будівництво мережі елеваторів. ТОВ «Катеринопольський } \\
\text { елеватор»: забезпечення комбікормами. ТОВ «Агрофорт»: вирощу- } \\
\text { вання зернових і технічних культур, виробництво молока й відгодівля } \\
\text { ВРХ. ТОВ «Урожай»: вирощування зернових культур }\end{array}$ \\
\hline $\begin{array}{c}\text { Виробництво протеїну та } \\
\text { рослинної олії }\end{array}$ & $\begin{array}{l}\text { ВАТ «Миронівський завод із виготовлення круп і комбікормів»: ком- } \\
\text { бікормовий і протеїновий заводи, } 3 \text { зернових елеватори і крупозавод }\end{array}$ \\
\hline $\begin{array}{c}\text { Зберігання зернових культур } \\
\text { і виробництво комбікормів }\end{array}$ & $\begin{array}{c}\text { Таврійський філіал Миронівського ЗПК, Новомосковський філіал ЗАТ } \\
\text { «Орель-Лідер»: елеватор, ТОВ «Катеринопільський елеватор»: } \\
\text { елеватор, виробництво комбікормів }\end{array}$ \\
\hline $\begin{array}{c}\text { Вирощування батьківського } \\
\text { поголів'я курчат - бройлерів } \\
\text { і виробництво інкубаційного } \\
\text { яйця }\end{array}$ & $\begin{array}{c}\text { СТОВ «Старинська птахофабрика», ДП «Птахофабрика Шахтарська } \\
\text { Нова», ТОВ «Миронівська птахофабрика» }\end{array}$ \\
\hline $\begin{array}{c}\text { Виробництво м’яса } \\
\text { курчат-бройлерів }\end{array}$ & $\begin{array}{c}\text { ДП «Перемога Нова», 3АТ з ІІ «Орель-Лідер», ЗАТ «Дружба народів } \\
\text { Нова»: птахофабрика, ЗАТ «Миронівська бройлерна фабрика» }\end{array}$ \\
\hline $\begin{array}{l}\text { Тваринництво } \\
\text { Рослинництво }\end{array}$ & $\begin{array}{c}\text { ТОВ «Агрофірма Київська» (рослинництво, тваринництво, фрукти), } \\
\text { ЗАТ «Кримська фруктова компанія»(фрукти) }\end{array}$ \\
\hline $\begin{array}{c}\text { Виробництво та переробка } \\
\text { м'яса, м’ясних напів- } \\
\text { фабрикатів, включаючи } \\
\text { виробництво делікатесної } \\
\text { яловичини } \\
\end{array}$ & $\begin{array}{c}\text { СТОВ «Дружба народів»: виробництво м’яса і м'ясопродуктів. } \\
\text { Миронівський м’ясопереробний завод «Легко»: } \\
\text { виробництво м'ясних напівфабрикатів }\end{array}$ \\
\hline $\begin{array}{l}\text { Виробництво делікатесної } \\
\text { гусячої печінки та гусячого } \\
\text { м'яса }\end{array}$ & $\begin{array}{l}\text { ЗАТ «Птахофабрика «Синятинська Нова»: } \\
\text { гусяче м’ясо та делікатесна гусяча печінка }\end{array}$ \\
\hline Дистрибуція & ВАТ «Миронівський хлібопрод \\
\hline Сервісні господарства & $\begin{array}{l}\text { ТОВ «Черкаський завод залізобетонних виробів»: виробництво збір- } \\
\text { них залізобетонних конструкцій сільськогосподарського призначення }\end{array}$ \\
\hline Роздрібна торгівля & Франчайзингові точки компанії \\
\hline
\end{tabular}

У 2009 р. врожайність зернових та олійних культур (кукурудза, соняшник, пшениця, ріпак, ячмінь та ін.) в компанії «Миронівський хлібопродукт» була вища, ніж середня врожайність в Україні. Компанія планує за 2-3 роки збільшити площі оброблюваних земель до 300-350 тис. га, що забезпечить ВАТ «Миронівський хлібопродукт» високий прибуток у рослинницькому сегменті бізнесу.

Стратегія компанії «Миронівський хлібопродукт» - це збереження своєї позиції лідера агропромислового ринку України шляхом розширення виробництва курятини і вирощування зернових, а також посилення вертикальної інтеграції [6]. Як провідний виробник курятини в Україні, згідно $з$ даними Держкомстату України, ВАТ «Миронівський хлібопродукт» у 2009 p. виробив близько 37 \% промислової курятини [6].
Головним конкурентом є ТОВ «Комплекс Агромарс», торговою маркою якої стали «Гаврилівські курчата». Дана компанія також активно використовує у своїй діяльності стратегічні принципи маркетингу.

Частки основних лідерів на ринку м'яса птиці України у 2010 р. зображено на рис.

Iз даних графіка видно, що агропідприємства, які використовують інноваційні стратегічні маркетингові підходи, (зокрема, ВАТ «Миронівський хлібопродукт» та ТОВ «Комплекс Агромарс») якісно відрізняються від тих підприємств, у яких маркетингові стратегії майже не використовуються.

Так, вказані вище агропідприємства виробляють 51 \% продукції ринку м'яса птиці в Україні по відношенню до решти подібних підприємств. 


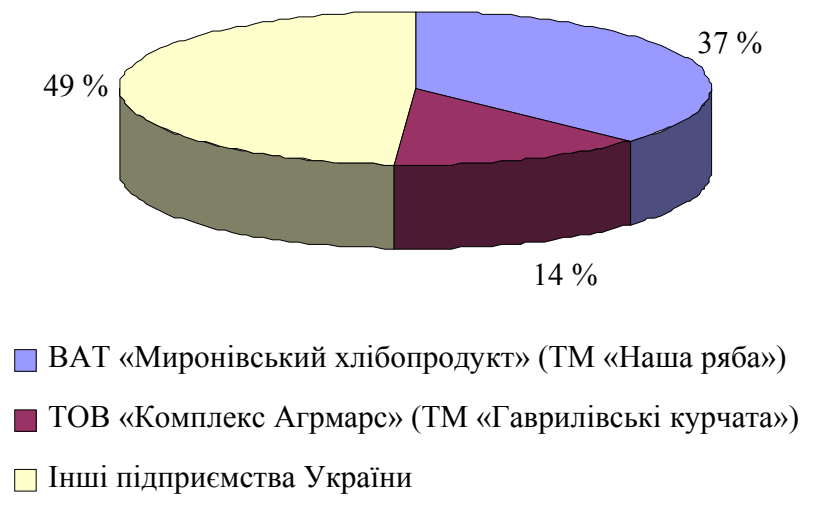

Рис. Частки лідерів на ринку м'яса птиці Украӥни, 2010 р.

Джерело: розроблено автором за даними офіційних сайтів ВАТ «Миронівський хлібопродукт» [6] i ТОВ «Комплекс Агромарс» [7]

Висновки. Формування маркетингової стратегії - один із найсуттєвіших і найскладніших етапів процесу маркетингу. Здійснення маркетингових аналізів із метою розробки цілей, опрацювання стратегій забезпечить найкращі результати. Це досить складна річ в умовах постійної зміни факторів зовнішнього та внутрішнього середовищ маркетингу. Систематизація й аналіз даних усіх результатів про діяльність підприємства доцільно проводити на динамічній основі. Дотримання основних вимог до маркетингового аналізу дає змогу на кожному часовому відрізку мати необхідну інформацію для контролю або коригування маркетингової стратегії.

Розробка маркетингової стратегії, конкурент-

\section{БІБЛІОГРАФІЯ}

1. Артімонова I. В. Особливості формування і функціонування служби маркетингу на аграрних підприємствах / I. В. Артімонова // Формування ринкових відносин в Україні. - 2010. - № 1. - С. 8-85.

2. Зозульов $O$. До питання про методологічну основу формування рішень у бізнесі / О. Зозульов // Банківська справа. - 2010. - № 2/3. - С. 71-77.

3. Сранкін O. О. Періодизація еволюції маркетингу в АПК України та перспективи його розвитку / О. О. Сранкін // Економіка АПК. - 2008. - № 1. C. 131-140.

4. Ламбен Ж.-Ж. Стратегический маркетинг: Европ. перспектива / Пер. с фр. - СПб. : Наука, 1996. $-589 \mathrm{c}$.

5. Мельник Д. Л. Маркетингова стратегія підприємства / Д. Л. Мельник // Вісник Хмельницького національного університету. - 2009. - № 3. C. 213-219.

6. Офіційний сайт компанії «Миронівський хлібо- ної в ринкових умовах, є досить складним процесом, а відтак його виконання повинне грунтуватися на системному підході, що відповідає наступним вимогам:

- загальною основою планування повинна стати система об'єктивних економічних законів, передусім законів попиту і пропозиції;

- планування грунтується на вивченні середовища ринку, а також тенденцій і закономірностей розвитку об'єкта планування;

- стратегії фіксуються шляхом визначення принципів поведінки всіх учасників ринку (споживачів, постачальників, виробників) і встановлення генеральної лінії поведінки підприємства на ринку.

продукт» [Електронний ресурс]. Режим доступу: http://www.mhp.com.ua/.

7. Офіційний сайт ТОВ «Комплекс Агромарс» [Електронний ресурс]. Режим доступу: http://www.agromars.com.ua/

8. Портер М. Международная конкуренция / Пер. с англ. - М. : Междунар. отношения, 1993. - 896 с.

9. Романюк О. П. Досягнення компанії «Миронівський хлібопродукт» / О. П. Романюк // Корпоративне видання - Миронівський хлібопродукт. 2010. - № 3. - C. 4-6.

10. Сухорська У. Р. Підходи до визначення маркетингової стратегії у практичній діяльності підприємств / У. Р. Сухорська, Н. Б. Ярошевич // Науковий вісник. - 2010. - №16. - С. 220-223.

11. Юрченко О. А. Переваги використання маркетингу на підприємствах АПК / О. А. Юрченко // Маркетинг в Україні. - 2010. - № 2. - С. 22-30. 